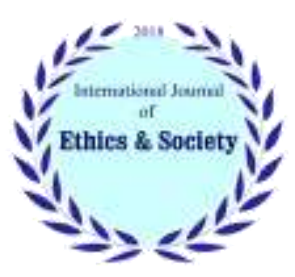

International Journal of Ethics \& Society (IJES)

Journal homepage: $\underline{\text { www.ijethics.com }}$

Vol. 3, No. 4 (2022)

(Original article)

\title{
Provide an Ethical Model for Using Social Networks in Providing Products, Services \& Maintaining Customer Responsibility
}

\author{
Mohammad Reza Kia , Ali Reza Kia ${ }^{b^{*}}$, Kamal Ghalandari ${ }^{c}$ \\ a) Dept. of Management, Central Tebran Branch, Islamic Azad University, Tebran, Iran \\ b) Dept. of Business Management, Science and Research Branch, Islamic Azad University, Tehran, Iran \\ c) Dept. of Business Management, Payame Noor University, Iran
}

\section{Abstract}

Background: The advent of social networks has created an easy way and cost-effective communication between the company and its customers and the need for them to pay attention to the ethical components in providing services and attract customer loyalty has led this research to provide an ethical model in using networks. Social in providing products and services and maintaining customer loyalty in banks.

Method: The present study was qualitative and the method of process team analysis was used. The statistical population was the banking industry experts, 14 of whom were selected by purposive sampling method (snowball). The interview data collection tool was semi-structured and thematic analysis using MAXQDA software was used to analyze the qualitative data.

Results: Based on the analysis of the interviews, 200 concepts were identified which, by reviewing the themes, 54 primary codes were extracted and classified into 3 main categories and 16 sub-categories. Customer loyalty is in the first place with 116 assigned codes, social networks are in the second place with 69 codes. Providing services with 15 codes is in the third place. The abundance of sub-criteria related to each category showed that service delivery, sub-category of service innovation, in social networks, sub-category of ethical communication, customer loyalty, sub-category of advertising and ethical marketing and economic growth, have the highest repetition.

Conclusion: From the perspective of banking industry experts, ethical components such as; Ethical branding, ethical-organizational factors, service innovation, ethical communication, content sharing, validation, cyberspace, customer value, customer trust, customer awareness, ethical advertising and marketing, customer desire, customer acquisition and retention, competitive advantage, Social responsibility, customer ethical attitude are among the factors affecting customer loyalty in social networks.

Keywords: Ethics, Social network, Provision of service

* Corresponding Author: Email: alirezakia58@gmail.com

Received: 04 Mar 2021

Accepted: 09 Apr 2021

Copyright: (C) 2022 Kia AR. et al. Published by Iranian Association of Ethics in Science and Technology

This article is an open access article distributed under a Creative Commons Attribution-Noncommercial 4.0

International License. (https://creativecommons.org/licenses/by-nc/4.0/ ). 


\section{Introduction}

Recent developments and the penetration of new social networks have fundamentally changed the way products, brands, partnerships and customer relationship management are introduced, and many businesses have begun to use these networks to provide services (1). Therefore, many companies have significantly increased their digital capabilities, skills and functions in order to maintain and compete in the market. For example, companies today are expected to maintain their presence on social networks such as Telegram, Facebook, WhatsApp, etc. to increase buyer engagement with their products and brands and their economic growth (2). The internet and social networks, which are among the largest sources of information, are growing day by day. The influence of social networks is such that consumers use them to obtain information about a particular product or service (3). Therefore, one of the main tools in the field of marketing and service delivery and customer acquisition is the use of social networks. Due to this, a great change has taken place in the field of service delivery and customer loyalty. The increasing development of service users and their interest in choosing the best services in terms of performance, have created many performance indicators in the field of service evaluation, which include: quality characteristics such as response time, availability, reliability and more (4). Social media can also be effective in maintaining customer loyalty. Creating and maintaining customer loyalty is one of the main research topics for marketers for a very long time $(5,6)$. Customer loyalty is one of the key aspects of customer relationship management (CRM). The neural network offers a framework for identifying the type of customer loyalty as Super Premium Loyal Customer (SPL), Loyal Premium Customers (PL), Valuable Customers (VC) and Normal Customers (NC) (7). But the question is how marketing with social media can play a role in maintaining customer loyalty. Social networks offer a new way to create a relationship between the consumer and the firm that can increase social interaction and the use of a particular brand by influencing the community, which results in the formation of consumer trust and brand loyalty. But in the meantime, in order to achieve the goal of enterprises, which is customer loyalty, it is very important to pay attention to the use of social networks to provide services from an ethical point of view. In addition to facilitating communication, social networks have posed ethical challenges to society that cannot be addressed with classical ethical approaches, so they need a new context and new ethical theories. In this regard, some contemporary philosophers have developed new ethical frameworks. They suggest that they can be a good ethical context for emerging technologies $(8,9)$.

Studies have shown that although some research has been done in the field of ethical marketing by social networks, but these researches are mostly in the form of modeling of foreign researches and comprehensive scientific research appropriate to the market and conditions of Iran has not been observed. Therefore, due to the importance of research in the field of using social media in marketing and presenting new products and the lack of research commensurate with the needs of the country, the need for research in this field is felt in the form of comprehensive research. The ethical model is the use of social networks in providing products and services and maintaining customer loyalty, and to know what are the most important factors affecting customer loyalty and marketing and presenting new products by ethical marketing in Iran.

\section{Material \& Methods}

The present study was qualitative and the process team analysis method was used. Also, this research was fundamental in terms of orientation and exploratory in terms of purpose. The statistical population was the banking industry experts who were selected by purposive sampling method (snowball) of 14 experts. Also, in this research, theoretical sampling has been used in order to adequate sampling. Theoretical sampling is the process of collecting data to generate a theory by which the analyst simultaneously collects, encodes, and analyzes his 
data and decides what to do in the future to improve his theory until it emerges. Where to collect data. The criterion for judging when to stop theoretical sampling is the theoretical adequacy of the categories or theories. That is, sampling continues until the next sample adds complementary material to the components of the theory. The interview data collection tool was semi-structured. In this study, in order to validate the categories and their relationships, the researcher has tried to regularly refine the theory by repeatedly returning to the research data, i.e. the continuous interaction between what is known and what should be known. In addition to conceptual density, theory should have a necessary and special conceptual distinction. Then, with the aim of improving the model and increasing its credibility, the model was presented to a number of key interviewees during the model sessions, and after obtaining their opinions and making some corrections, the proposed model was obtained. Finally, thematic analysis was used to analyze qualitative data using MAXQDA software.

\section{Results}

In the creation of primary codes, as mentioned in the previous chapter, first, meaningful units of data are labeled using a concept name, and then, using more abstract letters, the resulting concepts are categorized. Using the interview tool, it was observed that 54 initial codes out of 200 concepts were identified. Then, by searching the themes and reviewing the themes, 54 primary codes are classified into 3 main categories and 16 subcategories.

Table1: Search themes

\begin{tabular}{|c|c|c|c|}
\hline Main categories & Subcategories & Initial codes & Repetition \\
\hline \multirow[t]{7}{*}{ 1. Provision of services } & \multirow[t]{3}{*}{ 1. Ethical branding } & 1. Bank brand development & 3 \\
\hline & & $\begin{array}{l}\text { 2. Ethical visual content related to the introduction of } \\
\text { bank branches }\end{array}$ & 1 \\
\hline & & 3. Ethical branding by users & 1 \\
\hline & \multirow{2}{*}{$\begin{array}{l}\text { 2. Organizational-ethical } \\
\text { factors }\end{array}$} & 4. Specialized and qualified manpower & 1 \\
\hline & & 5. Pay attention to the customer's voice & 3 \\
\hline & \multirow[t]{2}{*}{ 3. Service innovation } & 6. Digital technologies & 1 \\
\hline & & 7. Innovation in creating banking system services & 5 \\
\hline \multirow[t]{11}{*}{ 2. Social media } & \multirow{3}{*}{$\begin{array}{l}\text { 4. Ethical communica- } \\
\text { tion }\end{array}$} & 8. Establish and develop ethical communication & 16 \\
\hline & & 9. Correct news and information & 6 \\
\hline & & 10. Easy access for everyone & 7 \\
\hline & \multirow[t]{3}{*}{ 5. Content sharing } & 11. Creating group social media of banks & 1 \\
\hline & & 12. Virtual media content & 2 \\
\hline & & $\begin{array}{l}\text { 13. Sharing and interacting with opinions and experi- } \\
\text { ences }\end{array}$ & 10 \\
\hline & \multirow[t]{2}{*}{ 6. Validation } & 14. Ranking of users by getting likes & 4 \\
\hline & & 15. Calculate risk for lenders & 1 \\
\hline & \multirow[t]{3}{*}{ 7. Cyberspace } & 16. The pervasiveness of cyberspace & 9 \\
\hline & & 17. Website & 3 \\
\hline & & 18. Telegram channels & 10 \\
\hline \multirow[t]{14}{*}{ 3. Customer loyalty } & \multirow[t]{2}{*}{ 8. Customer value } & 19. Added value & 1 \\
\hline & & 20. Receive value & 2 \\
\hline & \multirow[t]{3}{*}{ 9. Customer trust } & 21. Privacy of customer information & 2 \\
\hline & & 22. Strengthen public trust & 2 \\
\hline & & 23. The level of customer trust in the brand & 1 \\
\hline & \multirow[t]{3}{*}{ 10. Customer awareness } & 24. Mobile Bank training videos & 1 \\
\hline & & 25. Raise brand awareness & 1 \\
\hline & & 26. Customer knowledge and awareness & 3 \\
\hline & \multirow{6}{*}{$\begin{array}{l}\text { 11. Ethical advertising } \\
\text { and marketing }\end{array}$} & 27. Advertising campaigns & 3 \\
\hline & & 28. Gift card & 1 \\
\hline & & 29. Holding the festival & 1 \\
\hline & & 30. Advertising costs & 2 \\
\hline & & $\begin{array}{l}\text { 31. Access to a wide range of audiences and markets on } \\
\text { social media }\end{array}$ & 1 \\
\hline & & 32. Recommend to friends and reference groups & 1 \\
\hline
\end{tabular}


Kia AR. et al.

International Journal of Ethics \& Society (IJES), (2022) Vol. 3, No. 4

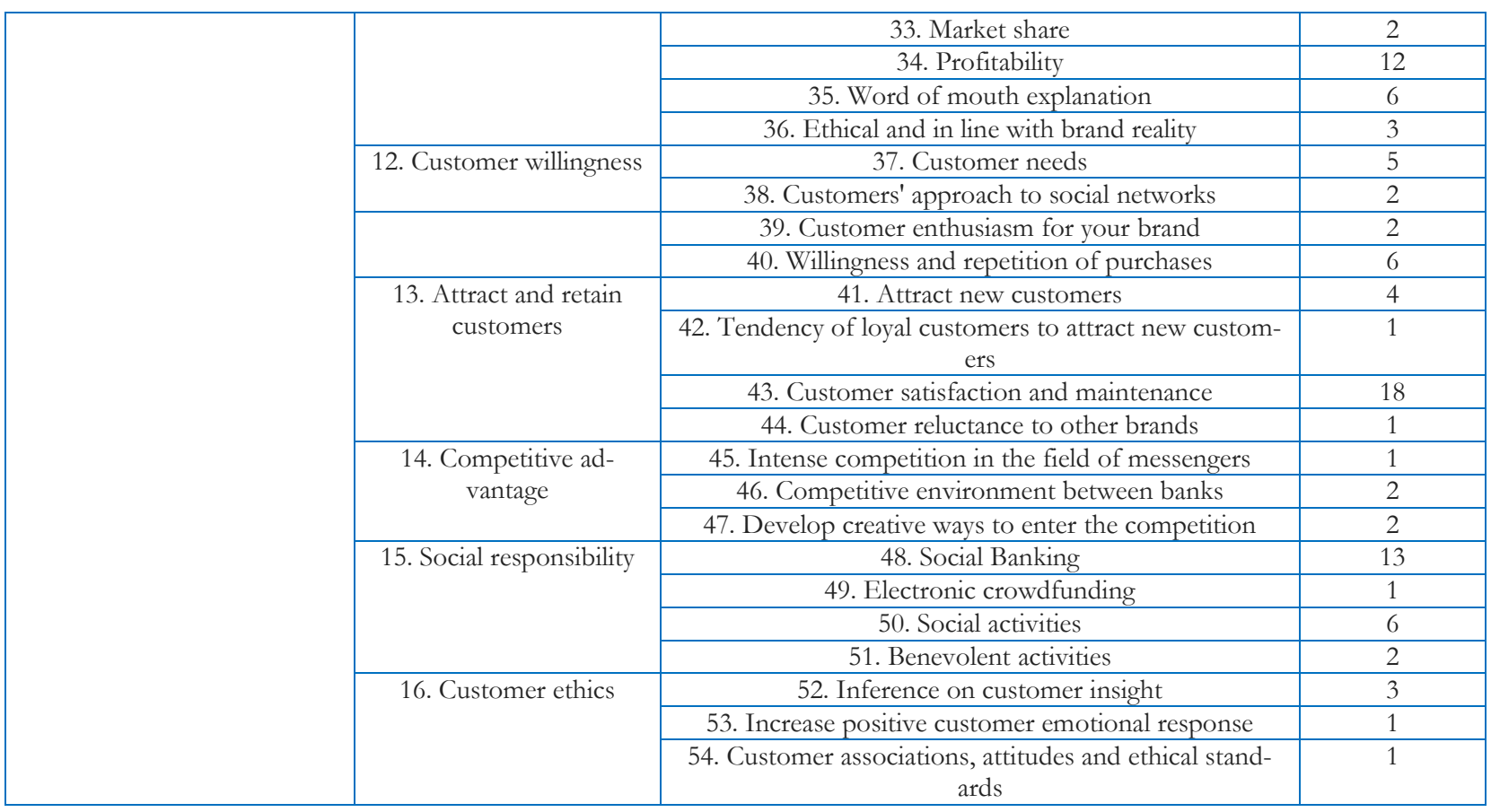

According to the chart and table above, the category of customer loyalty with 116 assigned codes is in the first place, social networks with 69 codes are in the second place. Providing services with 15 codes is in the third place.

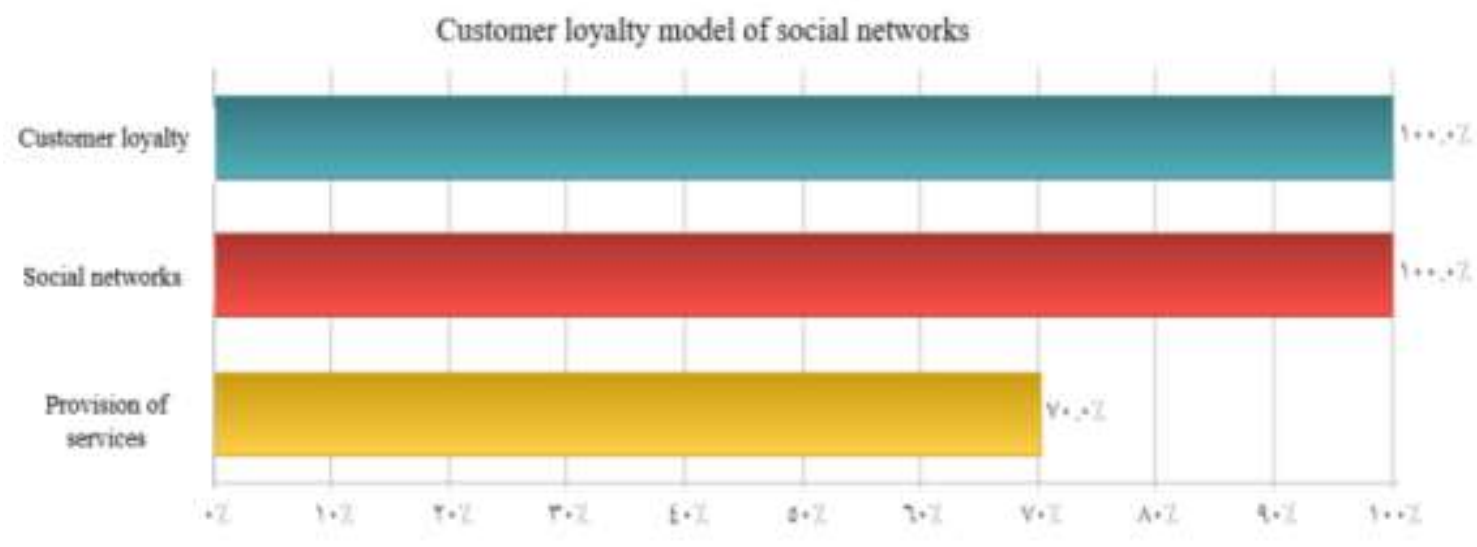

Fig.1: Percentage of interviewees by category identification

It can be seen that the percentage of reference to the category of customer loyalty was obtained by the interviewees equal to $100 \%$. In other words, everyone has referred to this category. Therefore, the category of customer loyalty is a priority in the number of codes counts and in terms of generality and inclusiveness in all respondents, which shows the importance of this category. The category of service provision has been mentioned by $70 \%$ of the respondents who have the lowest frequency. Finally, the main category of customer loyalty model can be seen in social networks, subcategories and open codes of each of them can also be viewed and reviewed. 


\section{Discussion}

According to the interviews and opinions obtained from experts, the category of customer loyalty with 116 assigned codes is in the first place, social networks with 69 codes are in the second place. Providing services with 15 codes is in the third place. The abundance of sub-criteria related to each category showed that service delivery, subcategory of service innovation, in social media, sub-category of ethical communication, in customer loyalty, sub-category of advertising and ethical marketing, have the highest repetition. Therefore, according to the results of the present study, it can be said that paying attention to the ethical components in the use of social networks by marketers is of great importance in maintaining customer loyalty and forming brand trust. This has been confirmed in various studies (10-13).

According to the identified dimensions and indicators, it is recommended:

- Considering the results obtained and the role of social media in the development of customer loyalty, it is suggested that Telegramapproved versions be provided to customers for easy access to banking services. So that all customers can easily use this social media to do their activities.

- Considering the importance of services and its impact on customer loyalty, it is recommended that the bank introduce and inform its new services through its social media and the methods of using these media in the field of new services are well trained. Be.

- It is necessary to provide online education for service customers through social media.

- When visiting the bank in person, the required applications should be installed on the customers' phones by the employees in charge of providing electronic services.

- According to the obtained results, there is a need for serious planning of banks at the macro level for official presence in social media and the need for advertising presence and exploitation of information and measuring public taste in these media.

\section{Conclusion}

In addition to the corporate connections that are formed in the context of specialized social networks and have huge economic benefits for the parties, from a business point of view, any user of social networks can be considered a potential customer. Data on users' behavior in the media and their interactions and interests can be an important source of information for companies, organizations and governments. This reveals the importance of mass media interests and exposing the desired products and services to the producers of products and services.

Banks and other financial and credit institutions around the world use social networks and media as a channel of communication with the audience. Banks on social media can fire directly at targets. Social media can be the biggest way for banks to advertise. Leading banks in the banking industry today use all the capacity of social networks to be more visible. In this way, in order to attract more customers and maintain their trust, they pay attention to the ethical components and even use charitable and environmental activities as a basis for introducing their services and products. Entering this new field, banks use different methods to attract the attention of social network users and pursue different goals.

Social networks have opened a good platform for presenting innovations and new services of banks and have made their marketing low-cost, useful and targeted. Most banks today prefer to offer their advertisements in these networks with a large number of users to promote their banking brand to help more. Nowadays, if banks want to survive and gain a competitive advantage, they must not only pay special attention to social networks as new communication channels for providing services, but also in presenting and introducing their services in this network. Pay attention to a set of ethical principles in order to gain customer loyalty and trust. From the perspective of banking industry experts in the present study, ethical components such as; Ethical branding, ethical-organizational factors, service innovation, ethical communication, content sharing, validation, cyberspace, 
customer value, customer trust, customer awareness, ethical advertising and marketing, customer desire, customer acquisition and retention, competitive advantage, Social responsibility, customer ethical attitude are among the factors affecting customer loyalty in social networks.

\section{Ethical Consideration}

Ethical issues (such as plagiarism, conscious satisfaction, misleading, making and or forging data, publishing or sending to two places, redundancy and etc.) have been fully considered by the writers

\section{Conflict of Interest}

The authors declare that there is no conflict of interests.

\section{Acknowledgement}

Researchers consider it necessary to thank and appreciate all the participants who helped us in this research.

\section{References}

1. Batra R, Keller KL (2016). Integrating marketing communications: new findings, new lessons, and new ideas. Journal of Marketing, 80(6): 122-145. DOI: http://dx.doi.org/10.1509/im.15.0419

2. American Bankers Association. (2017). The state of social media in banking. Results of an American Bankers Association, 1-22.

3. Bilgin $\mathrm{Y}$ (2018). The effect of social media marketing activities on brand awareness, brand image and brand loyalty. BMIJ, 6(1): 128-148. DOI: http://dx.doi.org/10.15295/v6i1.229

4. Yahyaoui H, Own HS (2018). Unsupervised clustering of service performance behaviors. Information Sciences,
422:

$558-571$

DOI:

https://doi.org/10.1016/i.ins.2017.08.065

5. Ariffin HF, Omar MS, Ahmad R (2016). Service quality, customers' satisfaction and the moderating effects of gender: A study of Arabic restaurants. Procedia-Social and Behavioral Sciences, 224: 384-392. DOI: https://doi.org/10.1016/i.sbspro.2016.05.393

6. Cova B, Pace S, Skalen P (2015). Brand volunteering: Value co-creation with unpaid consumers. Marketing Theory, 15(4): 465-485. DOI: https://doi.org/10.1177\%2F1470593115568919

7. Ghezzi A, Gastaldi L, Lettieri E, Martini A, Corso M (2016). A role for startups in unleashing the disruptive power of social media. International Journal of Information Management, 36: 1152-11590. $\quad$ DOI: https://doi.org/10.1016/i.ijinfomgt.2016.04.007

8. Kaplan A, Haenlein M (2010). Users of the world, unite the challenges and opportunities of social media. Business Horizons, 53: 59-68.

9. Schulze C, Schole L, Skiera B (2015). Customizing social media marketing. MIT Sloan Management Review, 56 (2): 810. DOI: https://orcid.org/0000-0001-9285-2013

10. Mutero WN (2014). Effect of social media interactions on financial performance of commercial banks in Kenya. [Ph. D thesis]. Kenya: University of Nairobi.

11. Stutzman $F(2006)$. An evaluation of identity-sharing behavior in social network communities. Joumal of the International Digital Media and Arts Association, 3 (1): 10-18.

12. Hennig Thurau T, Malthouse EC, Friege $C$, Gensler $\mathrm{S}$, Lobschat L, Rangaswamy A, Skiera B (2010). The impact of new media on customer relationships. Journal of Service Research, 13 (3): 311-330. DOI: https://doi.org/10.1177\%2F1094670510375460

13. Lusch R, Nambisan $S$ (2015). Service innovation: A service-dominant logic perspective. MIS Quarterly, 39 (1): 155-175.

DOI: http://dx.doi.org/10.25300/MISQ/2015/39.1.07 